\title{
Gene expression in the mouse preimplantation embryo
}

\author{
Jo-Ann L. Stanton, Andrew B. Macgregor and David P. L. Green* \\ Department of Anatomy and Structural Biology, University of Otago Medical School, \\ PO Box 913, Dunedin, New Zealand
}

\begin{abstract}
Mouse preimplantation development represents a tightly controlled programme of gene expression and cell division, which starts with the fertilized egg and ends with implantation of the blastocyst approximately 4.5 days later. Spatial and temporal differences in gene expression underpin establishment of axes at the two-cell stage and development of the trophectoderm and inner cell mass after embryo compaction at the eight-cell stage. Approximately 15700 mouse genes expressed during preimplantation development have been identified from cDNA sequences deposited in the UniGene database of the National Institutes of Health. This inventory of preimplantation genes is the starting point for identifying signalling modules that function in preimplantation development.
\end{abstract}

Important patterning events occur during mouse preimplantation development, which starts with the fertilized egg and ends with implantation of the blastocyst approximately 4.5 days later. Compaction at the eightcell stage followed by asymmetric cell division creates an outer epithelial cell layer that surrounds the inner cell mass (ICM) and allows formation of the blastocoel. Superimposed on these large-scale changes is the development of axes that anticipate the body axes of the implanted embryo.

There are a number of experimental features that make mouse preimplantation development an attractive model for studying mammalian differentiation and patterning: (i) the ability to culture fertilized eggs through to blastocysts in vitro; (ii) embryonic staging by visual inspection; (iii) development in simple media without extrinsic cues; and (iv) a large catalogue of expressed genes.

This review is divided into three sections. The first deals with the use of computational genomics to produce an inventory of about 15700 mouse preimplantation genes. The second section outlines briefly the current status of preimplantation development, and the third section discusses the potential of functional genomics to identify key genes that play a role in this development.

\section{Establishing a draft inventory of genes expressed in mouse preimplantation development}

Mammals possess about 200 different types of cell. Large numbers of expressed sequence tags (ESTs) have been obtained for many of these types of cell through the construction of complementary DNA

*Correspondence

Email: david.green@stonebow.otago.ac.nz
(cDNA) libraries derived from tissues and organs. Most of these ESTs have been derived from either mouse or human material. Repositories of ESTs include the dbEST database at the National Institutes of Health (NIH; http://www.ncbi.nlm.nih.gov/dbEST/) and the RIKEN database (http://genome.gsc.riken.go.jp). This review focuses on the use of ESTs imported into the UniGene database (Boguski and Schuler, 1995; Schuler, 1997). This is for two reasons. First, relatively few RIKEN transcript sequences are derived from cDNA libraries for early embryos in mice (see the RIKEN mouse cDNA encyclopaedia at http://genome.gsc.riken.go.jp) and, second, most RIKEN transcript sequences in the public domain have been incorporated into the UniGene database, making the UniGene database the more comprehensive of the two.

The NIH UniGene database contains ESTs and mRNA sequences imported from the dbEST database. UniGene clusters these ESTs by searching for sequences shared in common. In principle, matching sequences will be present between transcripts from the same gene but not between transcripts from different genes. (For a fuller explanation of the methodology, see http://www.ncbi.nlm.nih.gov/UniGene). If properly constructed, the number of UniGene clusters should approximate to the number of genes in the genome. UniGene clusters are built from ESTs and mRNAs irrespective of their tissue source and large UniGene clusters may contain ESTs contributed by many tissues. At the present time, the human UniGene database (build no. 157 ) contains about $4 \times 10^{6}$ ESTs and mRNAs, which cluster to 115523 UniGenes. Figures for a recent mouse UniGene build (no. 118) are about $2.6 \times 10^{6}$ ESTs and mRNAs, generating 87543 clusters.

The overall number of genes in both the human and mouse genomes is a matter of considerable interest 
and one that is relevant to this discussion. The number of human genes has been estimated to be between 30000 and 81000 (Ewing and Green, 2000; Liang et al., 2000; Roest Crollius et al., 2000; Lander et al.,, 2001; Venter et al., 2001; Wright et al., 2001; Zhuo et al., 2001). (The much-quoted figure of 120000 genes in the title of the paper by Liang et al. (2000) was subsequently corrected to 81273 genes (see Corrections in Nature Genetics 26501 (2000)). By contrast, a recent analysis of mouse cDNAs produces a minimum estimate of 70000 transcriptional units for the mouse genome (Okazaki et al., 2002). (Transcriptional units are clusters of transcripts that contain a common core of genetic information. They include alternatively spliced transcripts but may not always be protein-coding RNAs.) There are several reasons for differences between the number of genes estimated by computational methods and by expressed sequence methods. One difference stems from biases in the training sets used for optimizing genefinding algorithms which limit the types of genes that are predicted computationally. A second difference stems from the distinction between genes for protein-coding sequences and genes for other types of transcript. Given the rigour of several recent EST clustering analyses including, in some cases, mapping of putative clusters to the genome, the higher figures for the number of genes (as transcriptional units) appear to be robust. There is now reasonable consistency in the number of genes estimated from expressed sequence (6500081000 genes for humans (Liang et al., 2000; Wright et al., 2001; Zhuo et al., 2001) and 70000 for mice (Okazaki et al., 2002)).

One of the key findings from analysis of gene expression in mice is the presence of significant amounts of non-protein-coding RNAs, in addition to protein-coding, alternatively spliced, polyadenylated, and initiated RNAs, sense and antisense RNAs and RNAedited transcripts (Okazaki et al., 2002). Most of these transcripts will be captured by conventional methods of capturing RNA and will contribute to any computational system for clustering transcripts, such as UniGene. The current number of UniGenes for the mouse (87543) is broadly commensurate with the number of genes recently estimated for the mouse using analysis of cDNAs (Okazaki et al., 2002), but the number of human UniGenes (115 523) is considerably larger than corresponding estimates. There may be a number of reasons for this disparity, including the possibility that human UniGene clusters that contain only one EST ('singletons') represent rare transcripts from genes with very low expression.

Two key features of UniGene databases that are fundamental to the analysis of gene expression in mouse preimplantation development are discussed in this review. First, many of the ESTs contributing to UniGene are derived from cDNA libraries that individually contribute large blocks of ESTs from defined tissue sources. Second, each originating cDNA library retains a dbEST library catalogue number and this number is preserved in each UniGene EST entry, making it possible to track and amalgamate distinct bodies of expressed sequence data from identifiable tissue sources (Stanton and Green, 2001a).

The UniGene databases for mice and humans are now very large and require specialized software to handle them if maximum value is to be extracted. A suite of programmes has recently been developed using Bioperl software, which allows rapid automated downloading and handling of UniGene libraries and integration with downloads of the entire UniGene and HomoloGene databases (J. L. Stanton, A. B. Macgregor and D. P. L. Green, unpublished). (These programs replace earlier library derivations using FileMaker Pro (Stanton and Green, 2001a,b, 2002). Note also that Stanton and Green (2001a,b, 2002) referred to UniGene library IDs. These UniGene IDs have now been replaced in the databases by dbEST library IDs. The conversion table is available from ftp://ftp.ncbi.nih.gov/repository/UniGene/ (file name Mm.UGLID_dbestLID)).

The mouse UniGene database contains about 150 $\mathrm{dbEST}$ libraries that are identifiably embryonic in origin and eighteen of these libraries are derived from stages of preimplantation development (unfertilized egg, fertilized egg, two-cell, four-cell, eight-cell and 16-cell embryos, and blastocyst). Collectively, these 18 libraries contain about 102000 ESTs and mRNAs and generate about 15700 UniGene clusters. Subject to the limitations of UniGene, this represents a draft inventory of mouse preimplantation genes. Not all these UniGenes will be for protein-coding RNAs.

The clear staging of the contributing cDNA libraries (for example, egg, two-cell embryo) allows use of these libraries to identify major changes in gene expression across the period of preimplantation development (Ko et al., 2000; Stanton and Green, 2001a,b, 2002). The absence of contamination by other cells also allows assignment of the entire gene expression profiles to defined types of cell; a single type in the case of the egg and two types of cell in the case of the blastocyst. This has enormous advantages in analysis of gene expression and places these particular dbEST libraries apart from most others in the UniGene database, which are derived from complex mixtures of types of cell.

Data derived from the eighteen preimplantation libraries can be used in two ways. First, they can be analysed for the UniGenes they contain to produce 'parts lists' (Stanton and Green, 2001b, 2002). For example, libraries can be amalgamated to generate inventories for individual preimplantation stages (for example, unfertilized egg, fertilized egg) or amalgamated to create a single composite inventory of genes expressed in preimplantation development (Stanton and Green, 2001b, 2002). Such inventories are becoming increasingly important as a starting point for identifying, for 
example, signalling pathways and gene expression circuitry. A number of these genes have orthologues in other species (notably humans, but also rats and rabbits) and these can be identified by mapping the preimplantation inventory of mice onto HomoloGene (http://www.ncbi.nlm.nih.gov/HomoloGene/; Stanton and Green, 2001b, 2002), which provides a robust inventory of orthologous genes that has the benefit of the extensive annotation of function available for many human genes. However, this comparative exercise also underscores the absence of many of the human orthologues of mouse embryonic genes in the human expressed sequence databases. A major future use for mouse embryonic sequence data is therefore to act as electronic probes of human and other mammalian genomes to identify as yet undiscovered orthologous developmental genes.

The second use of the eighteen mouse preimplantation libraries is to generate profiles of gene expression for the stages of preimplantation development and to use these profiles to detect differences in gene expression that are statistically significant (Stanton and Green, 2001a). Again, this comparative approach, which was originally performed with FileMaker Pro, is now performed rapidly and automatically using Bioperl software (J. L. Stanton, A. B. Macgregor and D. P. L. Green, unpublished). This use of UniGene databases has the great advantage that it gives direct access to changes in gene expression without the need to wait for DNA array or quantitative PCR data.

To summarize this section, the computational approaches discussed above provide a large draft inventory ('parts list') of mouse preimplantation genes. Information about these genes ranges from fragments of cDNA sequence without identifiable reading frames to fulllength transcripts with well-defined protein products and substantial additional annotation. A significant number of annotated preimplantation genes have already been identified (Green and Stanton, 2001b, 2002) using mapping of mouse inventories onto HomoloGene, although most of these genes are well-established genes used by a range of types of cell. What is lacking, at present, is full-length sequence data for many of the genes for which expression occurs predominantly in embryogenesis and particularly in the preimplantation embryo.

Despite this deficiency, the gene inventory is large enough to support a substantial functional genomics approach to mouse preimplantation development. The key developmental events that are underpinned by expression of this inventory of genes is briefly outlined below, before a discussion of some possible directions for this approach.

\section{Morphology of mouse preimplantation development}

Two key questions in mammalian preimplantation development are (i) what accounts for the emergence and developmental fates of the trophectoderm and ICM; and (ii) what accounts for the development of axes in the preimplantation embryo that anticipate the axes of the postimplantation embryo? To address these questions in molecular terms requires an understanding of the morphology of preimplantation development.

The unfertilized mouse egg is spherical, with an animal-vegetal $(\mathrm{A}-\mathrm{V})$ axis in which the animal pole is marked by attachment of the second polar body (Fig. 1a). This axis remains identifiable in the blastocyst (Fig. 1d,e). Mouse eggs are polarized along the A-V axis; the animal pole lies at the centre of a cap of plasma membrane, which is microvillus-free whereas the remainder of the egg is covered in microvilli.

Recent evidence indicates that axes that anticipate those of the embryo proper become specified at first cleavage or earlier (Weber et al., 1999; Gardner, 2001a; Zernicka-Goetz, 2002). First cleavage occurs in a plane that approximately bisects the fertilized egg and passes close to or through the A-V axis (Gulyas, 1975; Howlett and Bolton, 1985; Gardner, 2001b; Piotrowska and Zernicka-Goetz, 2001). This plane also defines an orthogonal axis that passes through the two half blastomeres (Fig. 1b). When the blastocyst is formed after several further cell divisions, its embryonic and abembryonic poles lie along this same orthogonal axis (Ciemerych et al., 2000), with the site of the first cleavage plane marking the boundary between polar (embryonic) and mural (abembryonic) trophectoderm (Fig. 1d). Evidence indicates that the first two-cell blastomere to undergo second cleavage forms the embryonic pole, and the second blastomere forms the abembryonic pole (Piotrowska et al., 2001). The polarity of the A-V axis is also preserved in the blastocyst. A cross-section of the blastocyst in the plane separating embryonic and abembryonic poles is elliptical (Fig. 1e), with the major axis (the original $\mathrm{A}-\mathrm{V}$ axis) marked by the second polar body (Gardner, 1997).

It is clear from these observations that the first cleavage division produces dissimilar half blastomeres. How this dissimilarity arises is still a matter of conjecture. The ovulated egg may contain an asymmetric distribution of specific mRNAs or transcription factors which results in differences at the two-cell stage. Alternatively, uneven allocation of components such as the cytoskeleton may cause the asymmetry. As mentioned previously, second cleavage is asynchronous (Gulyas, 1975; Piotrowska et al., 2001), with the first half blastomere to divide contributing predominantly to the embryonic part of the blastocyst (Piotrowska et al., 2001).

The other important conclusion to be drawn from these observations is that the site of blastocoel formation is an intrinsic property of the polarity established at the two-cell stage. The specification of the position of the cavity must therefore be due to cellular events that are set in train by first cleavage. This is a subtle effect imposed on the much more obvious determination of 


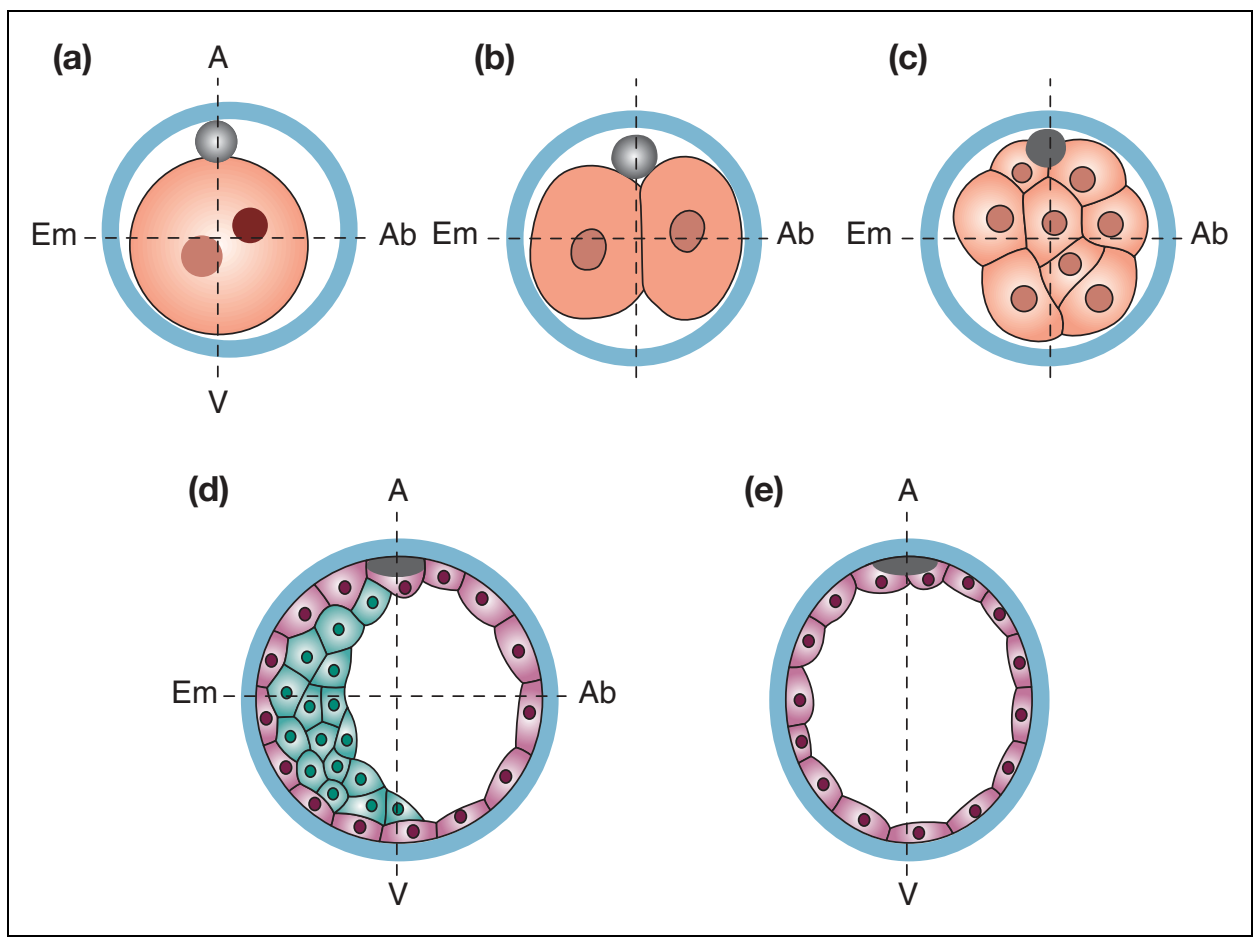

Fig. 1. Diagrammatic representation of four stages of mouse preimplantation development. The site of the second polar body (grey) and animal-vegetal $(\mathrm{A}-\mathrm{V})$ axis are shown in the same orientation throughout. (a) Fertilized egg showing both pronuclei. The future embryonic-abembryonic (Em-Ab) axis lies orthogonal to the A-V axis. (b) Two-cell embryo showing A-V axis and future Em-Ab axis. (c) Compacted 16-cell embryo. (d) Blastocyst shown in cross-section in the plane of the A-V and $\mathrm{Em}-\mathrm{Ab}$ axes, with the second polar body marking the boundary between polar and mural trophectoderm. (e) Cross-section of the same blastocyst rotated at right angles to (d), showing the ellipticity of the blastocyst along the A-V axis.

cell fate shown by the trophectoderm and ICM. Other evidence indicates that the first cleavage plane passes close to or through the site of sperm fusion (Piotrowska and Zernicka-Goetz, 2001; Plusa et al., 2002). Mouse spermatozoa can apparently fuse anywhere on the $80 \%$ of the egg surface covered in microvilli.

The pattern of cell division at second- and thirdcleavage divisions needs careful re-examination in the light of these data. The first of the two cell divisions at second cleavage occurs meridionally, in a plane that aligns approximately with the former A-V axis of the egg (Fig. 2). The second of the two-cell divisions starts in the same plane but this plane turns relative to the first two-cell division as cytokinesis proceeds, resulting in a plane separating the second pair of quarter blastomeres that lies at right angles to the first. This positions the four quarter blastomeres as a tetrahedron. Interestingly, the rotation of the second plane with respect to the first tends to occur preferentially in one direction in the rabbit, the only species in which it has been studied (Gulyas, 1975). This introduces chirality, with each of the quarter blastomeres potentially having different developmental potential. It is unknown whether this biased rotation occurs in mice and humans, and whether it has developmental significance.

The four-cell embryo cleaves to give the eightcell embryo, which undergoes compaction and formation of tight junctions shortly after third cleavage (Ziomek and Johnson, 1980; Johnson and Ziomek, 1981). Compaction produces apical and baso-lateral surfaces. Although each eight-cell blastomere has the appearance of equivalence, they cannot be equivalent in the undisturbed embryo as the eight-cell embryo carries an incipient embryonic-abembryonic (Em-Ab) axis (Ciemerych et al., 2000). Cell division of the eightcell embryo is geometrically heterogeneous, with some cells undergoing lateral division and some dividing along a radial axis. On average, about twice as many cells undergo lateral cell division as radial division, giving about a 2:1 ratio of outer to inner cells at the 16cell stage (Balakier and Pedersen, 1982; Fleming, 1987). Blastocoel formation begins at 32 cells and occurs in the abembryonic half of the Em-Ab axis established at first cleavage.

Late in blastocyst development, the ICM differentiates into epiblast and primitive endoderm. After implantation, 
the polar trophectoderm expands towards the abembryonic pole to form the extra-embryonic ectoderm and the primitive endoderm expands to become visceral and parietal endoderm, with epiblast lying between the two (see Beddington and Robertson, 1999). Endoderm originating from ICM cells close to the second polar body contributes to the proximal end of the egg cylinder whereas endoderm derived from cells at the far end of the major axis contributes to the distal end (Weber et al., 1999). The proximodistal axis of the egg cylinder descends directly from the Em-Ab axis of the blastocyst (Weber et al., 1999).

\section{Gene silencing: screening for preimplantation phenotypes}

The large inventory of mouse preimplantation genes described has the potential to be a major tool in understanding preimplantation developmental processes. One way in which it can be of value is to identify candidates for gene silencing, as, by silencing key genes, aberrant phenotypes that indicate functionally important mechanisms may be identified. This section begins with a discussion of the results of gene silencing using conventional knockout technology.

Numerous laboratories have produced mouse homozygous null mutations over the past 15 years that show lethal effects on mouse development; those that show a pre- or peri-implantation phenotype, principally lethality, are listed (Table 1). The appearance of a phenotype in homozygous null mutant embryos produced by mating heterozygous + /- carriers depends on eliminating maternal transcripts and then eliminating the translated protein. The earliest sign of any effect is shown by Rad51 and profilin 1 null mutants, which are lethal by first cleavage (Tsuzuki et al., 1996; Witke et al., 2001). This indicates that rapid turnover of maternal mRNA and protein after fertilization is possible. However, a significant number of null mutants show no lethality until embryonic day 4 (E4.0) or beyond, indicating either a much slower elimination of maternal transcripts and protein or a later onset of normal expression for these genes. In some cases, a mutant initially produces a hypomorphic phenotype which is then followed by embryonic death some days later (for example, Blm; Chester et al., 1998).

These data indicate that a pre- or peri-implantation phenotype can be caused by targeted gene silencing. All of the genes that have been reported as producing preimplantation lethality when silenced are found in the inventory of about 15700 preimplantation genes. Moreover, proteins that are physically associated with the products of these genes also appear in the inventory. Some examples are discussed here.

One of the more striking examples is shown by the four separate genes (Rad50, Brca1, Nbn and Blm), all of which cause early embryonic lethality when deleted.

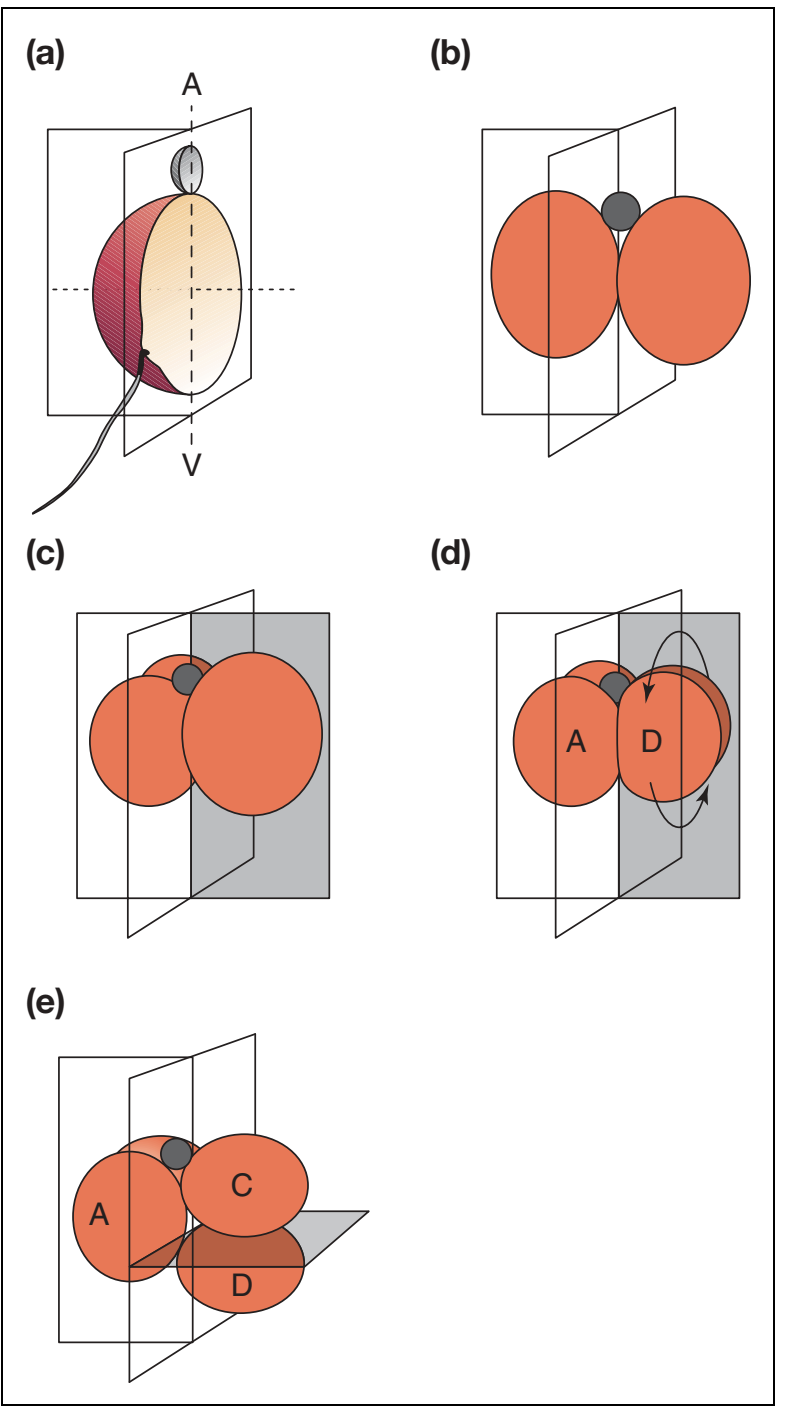

Fig. 2. Diagrammatic representation of the first two cleavages of the mouse egg (adapted from Gulyas, 1975). (a) Hemispheric section of a mouse egg through the second polar body. The section lies along the animal-vegetal $(\mathrm{A}-\mathrm{V})$ axis. The future embryonicabembryonic axis lies orthogonally. The site of sperm fusion is shown establishing the plane of first cleavage. (b) Two-cell embryo showing the second polar body close to the first cleavage plane and the A-V axis. (c) The position after the first half blastomere has undergone cleavage. (d) Four-cell embryo after cleavage of the second half blastomere. This view preserves the original cleavage planes. However, the cleavage plane of the second half blastomere turns during cytokinesis so that the second cleavage planes lie at right angles to each other; shown in (e). In the rabbit, this rotation takes place in a preferred direction (see Gulyas, 1975). No data are available for rotation in other species.

All four are part of the multi-molecular Brca1-associated genome surveillance complex (BASC) that is involved in double-stranded DNA break repair (Wang et al., 2000). The Nbn and Brca1 homozygous mutants are lethal by late-blastocyst stage (Liu et al., 1996; Zhu et al., 2001), and Rad50 and Blm produce visible 
J. L. Stanton et al.

Table 1. Mouse homozygous null mutants that show a pre- or peri-implantation phenotype

\begin{tabular}{|c|c|c|}
\hline Homozygous mouse mutant & $\begin{array}{l}\text { Time of first appearance of aberrant } \\
\text { phenotype }\end{array}$ & Reference \\
\hline $\begin{array}{l}\text { Rad51 } \\
\text { RAD51 homolog } \\
\quad \text { (Saccharomyces cerevisiae) }\end{array}$ & E1.0 & Tsuzuki et al., 1996 \\
\hline $\begin{array}{l}\text { Pfn1 } \\
\text { Profilin } 1\end{array}$ & E1.0 & Witke et al., 2001 \\
\hline $\begin{array}{l}\text { Sfrs3 } \\
\text { Splicing factor, arginine/serine- } \\
\quad \text { rich } 3 \text { (SRp20) }\end{array}$ & E2.0 & Jumaa et al., 1999 \\
\hline $\begin{array}{l}\text { Aplp2 } \\
\text { Amyloid beta (A4) precursor-like } \\
\text { protein } 2\end{array}$ & E2.0 & Rassoulzadegan et al., 1998 \\
\hline $\begin{array}{l}\text { Plcb3 } \\
\text { Phospholipase C, beta } 3\end{array}$ & Lethal at E2.5 & Wang et al., 1998 \\
\hline $\begin{array}{l}\text { Atp6I } \\
\text { ATPase, } \mathrm{H}^{+} \text {transporting, lysosomal } \\
\quad(\text { vacuolar proton pump) } 16 \mathrm{kDa}\end{array}$ & E2.5 & Inoue et al., 1999 \\
\hline $\begin{array}{l}\text { Tcl1 } \\
\text { T-cell lymphoma breakpoint } 1\end{array}$ & E2.5 & Narducci et al., 2002 \\
\hline $\begin{array}{l}\text { Incenp } \\
\text { Inner centromere protein }\end{array}$ & Visible effects by E2.5 & Cutts et al., 1999 \\
\hline $\begin{array}{l}\text { Racgap1 } \\
\text { RacGTPase-activating protein } 1\end{array}$ & Observable defects at E3.0 & Van den Putte et al., 2001 \\
\hline $\begin{array}{l}\text { Catna1 } \\
\text { Catenin alpha } 1 \text { ( } \alpha \text {-E-catenin) }\end{array}$ & E3.5 & Torres et al., 1997 \\
\hline $\begin{array}{l}\text { Trrap } \\
\text { Transformation/transcription domain- } \\
\quad \text { associated protein }\end{array}$ & E3.5 & Herceg et al., 2001 \\
\hline $\begin{array}{l}\text { Smn } \\
\text { Survival motor neurone }\end{array}$ & E3.5 & Schrank et al., 1997 \\
\hline $\begin{array}{l}\text { Txn } \\
\text { Thioredoxin }\end{array}$ & E3.5 & Matsui et al., 1996 \\
\hline $\begin{array}{l}\text { Nbn } \\
\text { Nibrin (nbs1) }\end{array}$ & About E4.0 & Zhu et al., 2001 \\
\hline $\begin{array}{l}\text { Ap1g1 } \\
\text { Adaptor A protein complex AP-1, } \\
\text { gamma } 1 \text { subunit ( } \gamma \text {-adaptin) }\end{array}$ & About E4.0 & Zizioli et al., 1999 \\
\hline $\begin{array}{l}\text { Madh2 } \\
\text { MAD homologue } 2 \text { (Drosophila) (Smad2) }\end{array}$ & $\begin{array}{l}\text { Effect on brachyury }(\mathrm{T}) \text { at E4.0, die at } \\
\text { E7.5 }\end{array}$ & Heyer et al., 1999 \\
\hline $\begin{array}{l}\text { Pou5f1 } \\
\text { POU domain, class 5, transcription } \\
\text { factor } 1 \text { (Oct } 4)\end{array}$ & Effect on ICM, E4.0 & Nichols et al., 1998 \\
\hline $\begin{array}{l}\text { Raly } \\
\text { hnRNP-associated with lethal yellow }\end{array}$ & $\mathrm{E} 4.0$ & Michaud et al., 1993 \\
\hline $\begin{array}{l}\text { Mbtps1 } \\
\text { Membrane-bound transcription factor } \\
\text { protease, site } 1\end{array}$ & E4.0 & Yang et al., 2001 \\
\hline $\begin{array}{l}\text { Tbn-pending } \\
\text { Taube nuss }\end{array}$ & E4.0 & Voss et al., 2000 \\
\hline $\begin{array}{l}\text { Bub3 } \\
\text { Budding uninhibited by benzimidazoles } 3 \\
\quad \text { homologue (S. cerevisiae) }\end{array}$ & $\begin{array}{l}\text { Normal to E3.5 but mitotic errors } \\
\text { from E4.5 }\end{array}$ & Kalitsis et al., 2000 \\
\hline
\end{tabular}

Continued. 
Table 1. (Continued)

\begin{tabular}{|c|c|c|}
\hline Homozygous mouse mutant & $\begin{array}{c}\text { Time of first appearance of aberrant } \\
\text { phenotype }\end{array}$ & Reference \\
\hline $\begin{array}{l}\text { Cdh1 } \\
\text { Cadherin } 1 \text { (E-cadherin) }\end{array}$ & About E4.5 & Larue et al., 1994 \\
\hline $\begin{array}{l}\text { Brca1 } \\
\text { Breast cancer } 1\end{array}$ & Effects detectable by E4.5 & Liu et al., 1996 \\
\hline $\begin{array}{l}\text { Vav } \\
\text { Vav oncogene }\end{array}$ & E4.5-E5.0 & Zmuidzinas et al., 1995 \\
\hline $\begin{array}{l}\text { Grb2 } \\
\text { Growth factor receptor-bound protein } 2\end{array}$ & E4.5-E5.0 & Cheng et al., 1998 \\
\hline $\begin{array}{l}\text { Cdc45I } \\
\text { Cell division cycle } 45 \text { homologue } \\
\quad(\text { S. cerevisiae-like })\end{array}$ & Between E4.5 and 5.5 & Yoshida et al., 2001 \\
\hline $\begin{array}{l}\text { Itgb1 } \\
\text { Integrin beta } 1 \text { (fibronectin receptor beta) }\end{array}$ & Normal at E4.5, degeneration by E5.5 & Stephens et al., 1995 \\
\hline $\begin{array}{l}\text { Yy1 } \\
\text { Yy1 transcription factor }\end{array}$ & $\begin{array}{l}\text { Implant but degenerate immediately, } \\
\text { E5.0 }\end{array}$ & Donohoe et al., 1999 \\
\hline $\begin{array}{l}\text { Ahcy } \\
\text { S-adenosylhomocysteine hydrolase }\end{array}$ & E5.0 & Miller et al., 1994 \\
\hline $\begin{array}{l}\text { O610007LO3Rik } \\
\text { RIKEN cDNA 0610007L03 gene (Srb7) }\end{array}$ & E5.0 & Tudor et al., 1999 \\
\hline $\begin{array}{l}\text { Refbp1 } \\
\text { RNA and export factor bonding } 1\end{array}$ & E5.5 & Xanthoudakis et al., 1996 \\
\hline $\begin{array}{l}\text { Mdm2 } \\
\text { Transformed mouse } 3 \text { T3 cell double minute } 2\end{array}$ & E5.5 & Montes de Oca Luna et al., 1995 \\
\hline $\begin{array}{l}\text { Cse1I } \\
\text { Chromosome segregation 1-like } \\
\quad \text { (S. cerevisiae) }\end{array}$ & Disorganized and degenerated by E5.5 & Bera et al., 2001 \\
\hline $\begin{array}{l}\text { Smarcc1 } \\
\text { SWI/SNF-related, matrix- associated, } \\
\text { actin-dependent regulator of chromatin }\end{array}$ & E5.5 & Kim et al., 2001 \\
\hline $\begin{array}{l}\text { Gata6 } \\
\text { GATA binding protein } 6\end{array}$ & E5.5 & $\begin{array}{l}\text { Morrissey et al., 1998; } \\
\text { Koutsourakis et al., } 1999\end{array}$ \\
\hline $\begin{array}{l}\text { Cul1 } \\
\text { Cullin } 1\end{array}$ & E5.5 & Dealy et al., 1999 \\
\hline $\begin{array}{l}\text { Pafah1b1 } \\
\text { Platelet-activating factor acetylhydrolase, } \\
\quad \text { isoform } 1 \mathrm{~b} \text {, beta } 1 \text { subunit }\end{array}$ & E5.5 & Hirotsune et al., 1998 \\
\hline $\begin{array}{l}\text { Cenpa } \\
\text { Centromere autoantigen A }\end{array}$ & Observable from E5.5 & Howman et al., 2000 \\
\hline $\begin{array}{l}\text { Ccna2 } \\
\text { Cyclin A2 }\end{array}$ & E5.5 & Murphy et al., 1997 \\
\hline $\begin{array}{l}\text { Trsp } \\
\text { tRNA phosphoserine }\end{array}$ & Die shortly after implantation, E5.5? & Bosl et al., 1997 \\
\hline $\begin{array}{l}\text { Rad51L1 } \\
\text { Rad51-like } 1 \text { (S. cerevisiae) }\end{array}$ & E5.5 & Shu et al., 1999 \\
\hline $\begin{array}{l}\text { Lamc1 } \\
\text { Laminin, gamma } 1\end{array}$ & E5.5 & Smyth et al., 1999 \\
\hline $\begin{array}{l}\text { Evx1 } \\
\text { Even-skipped homeotic gene } 1 \text { homolog }\end{array}$ & E5.5 & Spyropoulos and Capecchi, 1994 \\
\hline $\begin{array}{l}\text { Tsg101 } \\
\text { Tumour-susceptibility gene } 101\end{array}$ & E5.5, fail to develop past E6.5 & Ruland et al., 2001 \\
\hline
\end{tabular}

Continued. 
Table 1. (Continued)

\begin{tabular}{|c|c|c|}
\hline Homozygous mouse mutant & $\begin{array}{c}\text { Time of first appearance of aberrant } \\
\text { phenotype }\end{array}$ & Reference \\
\hline $\begin{array}{l}\text { Fgfr2 } \\
\text { Fibroblast growth factor receptor } 2\end{array}$ & Between E5.5 and E6.5 & $\begin{array}{l}\text { Arman et al., 1998; } \\
\quad \text { Haffner-Krausz et al., } 1999\end{array}$ \\
\hline $\begin{array}{l}\text { Ppp2ca } \\
\text { Protein phosphatase 2a, catalytic subunit, } \\
\text { alpha isoform }\end{array}$ & Between E5.5 and 6.5 & Gotz et al., 1998 \\
\hline $\begin{array}{l}\text { Rad50 } \\
\text { RAD50 homologue (S. cerevisiae) }\end{array}$ & Abnormal by $\mathrm{E} 6.0$ & Luo et al., 1999 \\
\hline $\begin{array}{l}\text { Rangap1 } \\
\text { RAN GTPase activating protein } 1(\sim \text { fug1, RNA1) }\end{array}$ & Arrest at egg cylinder stage, E6.0 & DeGregori et al., 1994 \\
\hline $\begin{array}{l}\text { Dsp } \\
\text { Desmoplakin }\end{array}$ & E6.0-E6.5 & Gallicano et al., 1998 \\
\hline $\begin{array}{l}\text { Blm } \\
\text { Bloom syndrome homologue (human) }\end{array}$ & $\begin{array}{l}\text { Late lethality, visible effects on } \\
\text { size by E6.5 }\end{array}$ & Chester et al., 1998 \\
\hline $\begin{array}{l}\text { Bmpr2 } \\
\text { Bone morphogenetic protein receptor } 2\end{array}$ & $\begin{array}{l}\text { Growth retarded and disorganized, } \\
\text { E6.5 }\end{array}$ & Beppu et al., 2000 \\
\hline $\begin{array}{l}\text { Xrcc1 } \\
\text { X-ray repair complementing defective } \\
\quad \text { repair in Chinese hamster cells } 1\end{array}$ & Arrest at E6.5 & Tebbs et al., 1999 \\
\hline $\begin{array}{l}\text { Btf3 } \\
\text { Basic transcription factor } 3\end{array}$ & Die at E6.5 & Deng and Behringer, 1995 \\
\hline $\begin{array}{l}\text { Clns1 } \\
\text { Chloride channel, nucleotide sensitive, 1a (ICln) }\end{array}$ & E3.5-E7.5 & Pu et al., 2000 \\
\hline
\end{tabular}

effects by E6.5 (Chester et al., 1998; Luo et al., 1999). All four are in the inventory of preimplantation genes, along with other components of BASC (Msh2, Msh6, Mlh1, Mre11, Rfc1, Rfc2, Rfc4). Brca1 and Brca2 are involved in maintenance of chromosome stability as well as DNA repair and recombination, cell-cycle control and transcription (Venkitaraman, 2002). The yeast Saccharomyces cerevisiae possesses a DNA damage repair network that has recently been characterized in considerable detail by mass spectrometry of the purified complex (Ho et al., 2002). Components of this network overlap with that in mammals, providing structural support for the function of DNA damage repair in mice and humans.

Other early embryonic-lethal genes that may also be involved in DNA repair include Rad51 and Rad51/1 as well as $X r c c 1$, for which the null mutant produces complete developmental arrest at E6.5 (Tsuzuki et al., 1996; Shu et al., 1999; Tebbs et al., 1999). Xrcc1 is part of a complex involved in single strand repair that includes polynucleotide kinase (Pnk), DNA polymerase$\mathrm{B}(\mathrm{Pol})$, and DNA ligase III (Lig3) (Whitehouse et al., 2001). Again, all have transcripts in the preimplantation gene inventory. Early homozygous lethal mutants that are also associated with genomic segregation and mitotic progression include Aplp2, two centromere proteins (Incenp, Cenpa), as well as the checkpoint protein Bub3 (Rassoulzadegan et al., 1998; Cutts et al., 1999; Howman et al., 2000; Kalitsis et al., 2000). Other early lethal phenotypes are associated with chromatin modification (Smarcc1, Trrap), mRNA splicing (Smn, Sfrs3) and RNA binding (Raly, Refbp1) (Michaud et al., 1993; Xanthoudakis et al., 1996; Schrank et al., 1997; Jumaa et al., 1999; Herceg et al., 2001; Kim et al., 2001).

These genes are likely to show early embryonic lethality because they play key roles in cells in general, the early embryo being merely the first opportunity for expression of the null phenotype. Of more interest in the context of developmental mechanisms are genes that produce selective effects, either on the trophectoderm or ICM. For example, three mutants, vav, cdh1 (E-cadherin) and $\alpha$-E-catenin, affect the trophectoderm but not the ICM. Vav immunoreactivity is found in the trophectoderm but not the ICM of E3.5 embryos and Vav (-/-) embryos fail to hatch at the blastocyst stage (Zmuidzinas et al., 1995). E-cadherin and $\alpha-E$-catenin are essential for the formation of tight junctions in the trophectoderm at the eight-cell stage 
(Larue et al., 1994; Torres et al., 1997). By contrast, the transcription factor Pou5f1 is expressed in the ICM and is essential for maintenance of its pluripotency (Nichols et al., 1998), and Grb2 and $\beta 1$ integrin play roles in its differentiation and maintenance (Stephens et al., 1995; Cheng et al., 1998). Taube nuss and Gata6 are transcription factors that act on the epiblast: taube nuss by suppressing apoptosis (Voss et al., 2000) and Gata6 by acting in extra-embryonic cells to maintain the epiblast (Koutsourakis et al., 1999). Other transcription factors that are homozygous lethal in mouse pre- or periimplantation development are Btf3, Mdm2 and $Y_{y} 1$ (Deng and Behringer, 1995; Montes de Oca Luna et al., 1995; Morrissey et al., 1998; Donohoe et al., 1999) and two other mutants have a direct effect on transcription: Madh2 (-/-) mutants show a premature rise in brachyury (T) expression at E4.0 (Heyer et al., 1999) and Mbtps1 is a membrane-bound transcription factor protease (Yang et al., 2001) that produces a phenotype by E4.0. These data are evidence that silencing transcription factors produces preimplantation phenotypes.

\section{Other approaches to gene silencing}

It has been recognized for some time that insertional mutagenesis ('gene trapping') in embryonic stem cells provides a route for construction of knockout mice. However, it relies on random insertions to produce silencing of genes which must then be characterized. Attempts to optimize the approach for genes of developmental interest has focused on the use of signal trapping to identify secreted and membrane proteins (Skarnes et al., 1995; Wiles et al., 2000; Mitchell et al., 2001). The rationale has been that membrane proteins and their ligands are likely to be important in development. Although this is true, it is also the case that many membrane and secreted proteins play no role in development, whereas key developmental proteins such as transcription factors have no signal sequence and will not be caught in a signal trap. A much more rapid route to screening for mutant phenotypes using gene silencing is likely to be RNA interference (RNAi). RNAi is one of a number of RNA silencing mechanisms used to eliminate defective mRNAs and defend organisms against genomic parasites (transposons and viruses; Zamore, 2002). RNAi using short sequences of double-stranded RNAs that contain the sequence of a specific gene frequently reduces or suppresses transcription, providing highly selective transcript knockdown. Importantly, there is strong evidence, using c-mos, $t-P A$ and Oct-3/4 as target species, that RNAi is effective at ablating gene transcripts in preimplantation development (Svoboda et al., 2000; Wianny and Zernicka-Goetz, 2000; Kim et al., 2002). RNAi has already greatly increased the speed of functional screening for mutant phenotypes in Caenorhabditis elegans (Zipperlen et al., 2001; Ashrafi et al., 2003; Kamath et al., 2003) in which, as is now the case in the mouse preimplantation embryo, the DNA sequences of a large number of candidate genes are known. The lack of full-length cDNAs for many UniGenes is not, in itself, an obstacle because of the shortness of the RNA sequences required for RNAi.

Despite the potential for high throughput screening using $\mathrm{RNAi}$, there remains a case for narrowing an initial screen because of the large starting number of candidates (about 15700). The most likely genes to be developmentally important are transcription factors, secreted proteins, surface receptors and signalling pathways. It is possible to undertake a computer-based screen for these proteins by integrating the preimplantation gene inventory with a keyword search in an appropriate database. Bioperl software has been used to integrate the results of a search of the NIH LocusLink database with UniGene-based libraries (J. L. Stanton, A. B. Macgregor and D. P. L. Green, unpublished). By way of example, a search in LocusLink on the keyword 'transcription factor' identifies a current total of 622 identified transcription factors for the complete mouse genome, of which 178 are expressed in the mouse preimplantation embryo. Interestingly, about 120 transcription factors have been identified for early Drosophila embryogenesis (Berman et al., 2002), a similar order of magnitude. A search of LocusLink using the keyword 'kinase' identifies 871 kinases or kinase-related proteins, of which 308 are expressed in mouse embryos before implantation. It can be argued that selected use of RNAi starting from a large inventory of known genes is inherently more inclusive and potentially faster than signal trapping in embryonic stem cells as a means of screening for developmentally interesting phenotypes, particularly with the arrival of electroporation of double-stranded RNAs into preimplantation embryos (Grabarek et al., 2002).

\section{Looking ahead}

One aim of this review has been to outline an approach using functional genomics to identify genes the expression of which determines patterning and differentiation in mouse preimplantation development. Although this inventory of genes is currently limited in its sequence lengths and annotation, two developments are under way that should greatly facilitate progress. The first is the increasing amount and quality of information about expressed sequence. The Mammalian Gene Collection (MGC) Program (2002) has signalled its goal of obtaining full-ORF (full-open reading frame) CDNA sequence and clones for each gene in humans and mice and the FANTOM Consortium is committed to expanding its coverage of the transcriptome in mice. Unfortunately, the time frame over which these efforts will be spread is not known. Mapping of mouse UniGenes onto the draft mouse genome is already under way and should help produce a rationalization of the mouse UniGene 
database analogous to that obtained with the human UniGene database (Zhuo et al., 2001). Mouse genes are increasingly well annotated and this improvement will feed back to generate a high-quality annotated catalogue of genes expressed in embryonic development in mice. HomoloGene is steadily expanding to identify human and other mammalian orthologues of mouse genes. Fly, nematode and zebra fish orthologues will also increasingly emerge, opening up the opportunity for comparative studies of early embryonic development.

The second facilitating development will be integrated efforts to identify signalling pathways. A major model initiative in this area is the Alliance for Cellular Signaling (AfCS), which aims to understand the signalling relationship between cellular inputs and outputs as completely as possible (http://www.afcs.org). AfCS has recently begun work on the extensive characterization of the mouse cardiac myocyte and the mouse splenic B cell. As neither of these types of cell expresses a developmental programme, there is a strong case for characterizing a well-defined mouse developmental system. The authors of this review propose mouse preimplantation development. Its advantages include development that produces a well-defined number of cells in a timetable that is consistent and short (4-5 days), development that is independent of external signals (which greatly simplifies analysis), a large inventory of expressed genes that are becoming increasingly annotated, and a developmental programme that can be targeted by RNA interference and characterized with DNA microarrays. Completion of the draft mouse, human and rat genomes will provide the additional opportunity to identify the cis-regulatory modules governing preimplantation gene expression as the $5^{\prime}$ ends of mouse preimplantation genes become identified.

This work was supported by grants from the Marsden Fund of the Royal Society of New Zealand and the New Economy Research Fund of the New Zealand Foundation for Research, Science and Technology.

\section{References}

Key references are identified by asterisks.

Arman E, Haffner-Krausz R, Chen Y, Heath JK and Lonai P (1998) Targeted disruption of fibroblast growth factor (FGF) receptor 2 suggests a role for FGF signaling in pregastrulation mammalian development Proceedings National Academy of Sciences USA 95 5082-5087

Ashrafi K, Chang FY, Watts JL, Fraser AG, Kamath RS, Ahringer J and Ruvkun G (2003) Genome-wide RNAi analysis of Caenorhabditis elegans fat regulatory genes Nature $\mathbf{4 2 1} 268-272$

Balakier H and Pedersen RA (1982) Allocation of cells to the inner cell mass and trophectoderm lineages in the preimplantation mouse embryo Developmental Biology 90 352-362

*Beddington RSP and Robertson EJ (1999) Axis development and early asymmetry in mammals Cell $\mathbf{9 6}$ 195-200

Beppu H, Kawabata M, Hamamoto T, Chytil A, Minowa O, Noda T and Miyazono K (2000) BMP type II receptor is required for gastrulation and early development of mouse embryos Developmental Biology 221 249-258
Bera TK, Bera J, Brinkmann U, Tessarollo L and Pastan I (2001) Cse1l is essential for early embryonic growth and development Molecular and Cellular Biology 21 7020-7024

Berman BP, Nibu Y, Pfeiffer BD, Tomancak P, Celniker SE, Levine M, Rubin GM and Eisen MB (2002) Exploiting transcription factor binding site clustering to identify cis-regulatory modules involved in pattern formation in the Drosophila genome Proceedings National Academy of Sciences USA 99 757-762

Boguski M and Schuler GD (1995) Establishing a human transcript map Nature Genetics 10 369-371

Bosl MR, Takaku K, Oshima M, Nishimura S and Taketo MM (1997) Early embryonic lethality caused by targeted disruption of the mouse selenocysteine tRNA gene (Trsp) Proceedings National Academy of Sciences USA 94 5531-5534

Cheng AM, Saxton TM, Sakai $\mathbf{R}$ et al. (1998) Mammalian Grb2 regulates multiple steps in embryonic development and malignant transformation Cell 95 793-803

Chester N, Kuo F, Kozak C, O'Hara CD and Leder P (1998) Stagespecific apoptosis, developmental delay, and embryonic lethality in mice homozygous for a targeted disruption in the murine Bloom's syndrome gene Genes and Development 12 3382-3393

*Ciemerych MA, Mesnard D and Zernicka-Goetz M (2000) Animal and vegetal poles of the mouse egg predict the polarity of the embryonic axis, yet are non-essential for development Development $1273467-$ 3474

Cutts SM, Fowler KJ, Kile BT, Hii LL, O'Dowd RA, Hudson DF, Saffery R, Kalitsis P, Earle E and Choo KH (1999) Defective chromosome segregation, microtubule bundling and nuclear bridging in inner centromere protein gene (Incenp)-disrupted mice Human Molecular Genetics 8 1145-1155

Dealy MJ, Nguyen KV, Lo J, Gstaiger M, Krek W, Elson D, Arbeit J, Kipreos ET and Johnson RS (1999) Loss of Cul1 results in early embryonic lethality and dysregulation of cyclin E Nature Genetics 23 245-248

DeGregori J, Russ A, von Melchner H, Rayburn H, Priyaranjan P, Jenkins NA, Copeland NG and Ruley HE (1994) A murine homolog of the yeast RNA1 gene is required for postimplantation development Genes and Development 8 265-276

Deng JM and Behringer RR (1995) An insertional mutation in the BTF3 transcription factor gene leads to an early postimplantation lethality in mice Transgenic Research 4 264-269

Donohoe ME, Zhang X, McGinnis L, Biggers J, Li E and Shi Y (1999) Targeted disruption of mouse Yin Yang 1 transcription factor results in periimplantation lethality Molecular and Cellular Biology 19 7237-7244

Ewing B and Green P (2000) Analysis of expressed sequence tags indicates 35,000 human genes Nature Genetics 25 232-234

Fleming TP (1987) A quantitative analysis of cell allocation to trophectoderm and inner cell mass in the mouse blastocyst Developmental Biology 119 520-531

Gallicano GI, Kouklis P, Bauer C, Yin M, Vasioukhin V, Degenstein L and Fuchs $\mathbf{E}$ (1998) Desmoplakin is required early in development for assembly of desmosomes and cytoskeletal linkage Journal of Cell Biology 143 2009-2022

Gardner RL (1997) The early blastocyst is bilaterally symmetrical and its axis of symmetry is aligned with the animal-vegetal axis of the zygote in the mouse Development 124 289-301

*Gardner RL (2001a) The initial phase of embryonic patterning in mammals International Review of Cytology 203 233-290

*Gardner RL (2001b) Specification of embryonic axes begins before cleavage in normal mouse development Development 128 839-847

Gotz J, Probst A, Ehler E, Hemmings B and Kues W (1998) Delayed embryonic lethality in mice lacking protein phosphatase 2A catalytic subunit C alpha Proceedings National Academy of Sciences USA 95 12370-12375

Grabarek JB, Plusa B, Glover DM and Zernicka-Goetz M (2002) Efficient delivery of dsRNA into zona-enclosed mouse oocytes and preimplantation embryos by electroporation Genesis 32 269-276

Gulyas B (1975) A re-examination of cleavage patterns in eutherian mammalian eggs: rotation of blastomere pairs during second cleavage in the rabbit Journal of Experimental Zoology 183 235-248 
Haffner-Krausz R, Gorivodsky M, Chen $\mathbf{Y}$ and Lonai $\mathbf{P}$ (1999) Expression of Fgfr2 in the early mouse embryo indicates its involvement in preimplantation development Mechanisms of Development 85 167-172

Herceg Z, Hulla W, Gell D, Cuenin C, Lleonart M, Jackson S and Wang ZQ (2001) Disruption of Trrap causes early embryonic lethality and defects in cell cycle progression Nature Genetics 29 206-211

Heyer J, Escalante-Alcade D, Lia M, Boettinger E, Edelmann W, Stewart CL and Kucherlapati R (1999) Postgastrulation Smad2-deficient embryos show defects in embryo turning and anterior morphogenesis Proceedings National Academy of Sciences USA 96 12 595-12 600

Hirotsune S, Fleck MW, Gambello MJ, Bix GJ, Chen A, Clark GD, Ledbetter DH, McBain CJ and Wynshaw-Boris A (1998) Graded reduction of Pafah1b1 (Lis1) activity results in neuronal migration defects and early embryonic lethality Nature Genetics 19 333-339

Ho Y, Gruhler A, Heilbut A et al. (2002) Systematic identification of protein complexes in Saccharomyces cerevisiae by mass spectrometry Nature 415 180-183

Howlett SK and Bolton VN (1985) Sequence and regulation of morphological and molecular events during the first cycle of mouse embryogenesis Journal of Embryology and Experimental Morphology 87 175206

Howman EV, Fowler KJ, Newson AJ, Redward S, MacDonald AC, Kalitsis P and Choo KH (2000) Early disruption of centromeric chromatin organization in centromere protein A (Cenpa) null mice Proceedings National Academy of Sciences USA 97 1148-1153

Inoue H, Noumi T, Nagata M, Murakami H and Kanazawa H (1999) Targeted disruption of the gene encoding the proteolipid subunit of mouse vacuolar $\mathrm{H}(+)$-ATPase leads to early embryonic lethality Biochimica et Biophysica Acta 1413 130-138

*Johnson MH and Ziomek CA (1981) The foundation of two distinct cell lineages within the mouse morula Cell 24 71-80

Jumaa H, Wei G and Nielsen PJ (1999) Blastocyst formation is blocked in mouse embryos lacking the splicing factor SRp20 Current Biology 9 899-902

Kalitsis P, Earle E, Fowler KJ and Choo KH (2000) Bub3 gene disruption in mice reveals essential mitotic spindle checkpoint function during early embryogenesis Genes and Development 14 2277-2282

Kamath RS, Fraser AG, Dong Y et al. (2003) Systematic functional analysis of the Caenorhabditis elegans genome using RNAi Nature 421 231237

Kim JK, Huh SO, Choi H et al. (2001) Srg3, a mouse homolog of yeast SWI3, is essential for early embryogenesis and involved in brain development Molecular and Cellular Biology 21 7787-7795

Kim M-H, Yuan X, Okumura S and Ishikawa F (2002) Successful inactivation of endogenous Oct-3/4 and c-mos genes in mouse preimplantation embryos and oocytes using short interfering RNAs Biochemical and Biophysical Research Communications 96 1372-1377

*Ko MS, Kitchen JR, Wang X et al. (2000) Large-scale cDNA analysis reveals phased gene expression patterns during preimplantation mouse development Development 127 1737-1749

Koutsourakis M, Langeveld A, Patient R, Beddington R and Grosveld F (1999) The transcription factor GATA6 is essential for early extraembryonic development Development 126 723-732

Lander ES, Linton LM, Birren B et al. (2001) Initial sequencing and analysis of the human genome Nature $\mathbf{4 0 9} 860-921$

Larue L, Ohsugi M, Hirchenhain J and Kemler R (1994) E-cadherin null mutant embryos fail to form a trophectoderm epithelium Proceedings National Academy of Sciences USA 91 8263-8267

Liang F, Holt I, Pertea G, Karamycheva S, Salzberg SL and Quackenbush J (2000) Gene index analysis of the human genome estimates approximately 120,000 genes Nature Genetics 25 239-240

Liu CY, Flesken-Nikitin A, Li S, Zeng Y and Lee WH (1996) Inactivation of the mouse Brca1 gene leads to failure in the morphogenesis of the egg cylinder in early postimplantation development Genes and Development 10 1835-1843

Luo G, Yao MS, Bender CF, Mills M, Bladl AR, Bradley A and Petrini JH (1999) Disruption of mRad50 causes embryonic stem cell lethality, abnormal embryonic development, and sensitivity to ionizing radiation Proceedings National Academy of Sciences USA 96 7376-7381
Mammalian Gene Collection (MGC) Program Team (2002) Generation and initial analysis of more than 15,000 full-length human and mouse cDNA sequences Proceedings National Academy of Sciences USA 9916899 16903

Matsui M, Oshima M, Oshima H, Takaku K, Maruyama T, Yodoi J and Taketo MM (1996) Early embryonic lethality caused by targeted disruption of the mouse thioredoxin gene Developmental Biology 178 179-185

Michaud EJ, Bultman SJ, Stubbs LJ and Woychik RP (1993) The embryonic lethality of homozygous lethal yellow mice (Ay/Ay) is associated with the disruption of a novel RNA-binding protein Genes and Development 7 1203-1213

Miller MW, Duhl DM, Winkes BM, Arredondo-Vega F, Saxon PJ, Wolff GL, Epstein CJ, Hershfield MS and Barsh GS (1994) The mouse lethal nonagouti $(\mathrm{a}(\mathrm{x}))$ mutation deletes the S-adenosylhomocysteine hydrolase (Ahcy) gene EMBO Journal 13 1806-1816

Mitchell KJ, Pinson KI, Kelly OG et al. (2001) Functional analysis of secreted and transmembrane proteins critical to mouse development Nature Genetics 28 241-249

Montes de Oca Luna R, Wagner DS and Lozano G (1995) Rescue of early embryonic lethality in $\mathrm{mdm} 2$-deficient mice by deletion of p53 Nature 378 203-206

Morrissey EE, Tang Z, Sigrist K, Lu MM, Jiang F, Ip HS and Parmacek MS (1998) GATA6 regulates HNF4 and is required for differentiation of visceral endoderm in the mouse embryo Genes and Development 12 3579-3590

Murphy M, Stinnakre MG, Senamaud-Beaufort C, Winston NJ, Sweeney C, Kubelka M, Carrington M, Brechot C and Sobczak-Thepot J (1997) Delayed early embryonic lethality following disruption of the murine cyclin A2 gene Nature Genetics 15 83-86

Narducci MG, Fiorenza MT, Kang SM et al. (2002) TCL1 participates in early embryonic development and is overexpressed in human seminomas Proceedings National Academy of Sciences USA 99 11 712-11 717

Nichols J, Zevnik B, Anastassiadis K, Niwa H, Klewe-Nebenius D, Chambers I, Scholer H and Smith A (1998) Formation of pluripotent stem cells in the mammalian embryo depends in the POU transcription factor Oct4 Cell 95 379-391

*Okazaki Y, Furuno M, Kasukawa T et al. (2002) Analysis of the mouse transcriptome based on functional annotation of 60,770 full-length cDNAs Nature 420 563-573

Piotrowska K and Zernicka-Goetz M (2001) Role for sperm in spatial patterning of the early mouse embryo Nature 409 517-521

Piotrowska K, Wianny F, Pedersen RA and Zernicka-Goetz M (2001) Blastomeres arising from the first cleavage division have distinguishable fates in normal mouse development Development 128 3739-3748

Plusa B, Piotrowska K and Zernicka-Goetz M (2002) Sperm entry position provides a surface marker for the first cleavage plane of the mouse zygote Genesis 32 193-198

Pu WT, Wickman K and Clapham DE (2000) ICIn is essential for cellular and early embryonic viability Journal of Biological Chemistry $27512363-$ 12366

Rassoulzadegan M, Yang Y and Cuzin F (1998) APLP2, a member of the Alzheimer precursor protein family, is required for correct genomic segregation in dividing mouse cells EMBO Journal 17 4647-4656

Roest Crollius H, Jaillon O, Bernot A et al. (2000) Estimate of human gene number provided by genome-wide analysis using Tetraodon nigroviridis DNA sequence Nature Genetics 25 235-238

Ruland J, Sirard C, Elia A, MacPherson D, Wakeham A, Li L, de la Pompa JL, Cohen SN and Mak TW (2001) p53 accumulation, defective cell proliferation, and early embryonic lethality in mice lacking tsg101 Proceedings National Academy of Sciences USA 98 1859-1864

Schrank B, Götz R, Gunnersen JM, Gunnersen JM, Ure JM, Toyka KV, Smith AG and Sendtner M (1997) Inactivation of the survival motor neuron gene, a candidate gene for human spinal muscular atrophy, leads to massive cell death in early mouse embryos Proceedings National Academy of Sciences USA 94 9920-9925

Shu Z, Smith S, Wang L, Rice MC and Kmiec EB (1999) Disruption of muREC2/RAD51L1 in mice results in early embryonic lethality which can be partially rescued in a p53(-/-) background Molecular and Cellular Biology 19 8686-8693 
Schuler GD (1997) Pieces of the puzzle: expressed sequence tags and the catalog of human genes Journal of Molecular Medicine 75 694-698

Skarnes WC, Moss JE, Hurtley SM and Beddington RS (1995) Capturing genes encoding membrane and secreted proteins important for mouse development Proceedings National Academy of Sciences USA 926592 6596

Smyth N, Vatansever HS, Murray P, Meyer M, Frie C, Paulsson M and Edgar D (1999) Absence of basement membranes after targeting the LAMC1 gene results in embryonic lethality due to failure of endoderm differentiation Journal of Cell Biology 144 151-160

Spyropoulos DD and Capecchi MR (1994) Targeted disruption of the evenskipped gene, evx1, causes early postimplantation lethality of the mouse conceptus Genes and Development 8 1949-1961

*Stanton JL and Green DPL (2001a) Meta-analysis of gene expression in mouse preimplantation embryo development Molecular Human Reproduction 7 545-552

*Stanton JL and Green DPL (2001b) A set of 840 mouse oocyte genes with well-matched human homologues Molecular Human Reproduction 7 521-543

*Stanton JL and Green DPL (2002) A set of 1542 mouse blastocyst and pre-blastocyst genes with well-matched human homologues Molecular Human Reproduction 8 149-166

Stephens LE, Sutherland AE, Klimanskaya IV, Andrieux A, Meneses J, Pedersen RA and Damsky CH (1995) Deletion of $\beta 1$ integrins in mice results in inner cell mass failure and peri-implantation lethality Genes and Development 9 1883-1895

*Svoboda P, Stein P, Hayashi H and Schultz RM (2000) Selective reduction of dormant maternal mRNAs in mouse oocytes by RNA interference Development 127 4147-4156

Tebbs RS, Flannery ML, Meneses JJ, Hartmann A, Tucker JD, Thompson LH, Cleaver JE and Pedersen RA (1999) Requirement for the Xrcc1 DNA base excision repair gene during early mouse development Developmental Biology 208 513-529

Torres M, Stoykova A, Huber O, Chowdhury K, Bonaldo P, Mansouri A, Butz S, Kemler $\mathbf{R}$ and Gruss $\mathbf{P}$ (1997) An $\alpha$-E-catenin gene trap mutation defines its function in preimplantation development Proceedings National Academy of Sciences USA 94 901-906

Tsuzuki T, Fujii Y, Sakumi K, Tominaga Y, Nakao K, Sekiguchi M, Matsushiro A, Yoshimura Y and Morita T (1996) Targeted disruption of the Rad51 gene leads to lethality in embryonic mice Proceedings National Academy of Sciences USA 93 6236-6240

Tudor M, Murray PJ, Onufryk C, Jaenisch R and Young RA (1999) Ubiquitous expression and embryonic requirement for RNA polymerase II coactivator subunit Srb7 in mice Genes and Development 132365 2368

Van de Putte $T$, Zwijsen A, Lonnoy O, Rybin V, Cozijnsen $M$, Francis A, Baekelandt V, Kozak CA, Zerial M and Huylebroeck D (2001) Mice with a homozygous gene trap vector insertion in mgcRacGAP die during preimplantation development Mechanisms of Development 102 33-44

Venkitaraman AR (2002) Cancer susceptibility and the functions of BRCA1 and BRCA2 Cell 108 171-182

Venter JC, Adams MD, Myers EW et al. (2001) The sequence of the human genome Science 291 1304-1351

Voss AK, Thomas T, Petrou P, Anastassiadis K, Scholer H and Gruss P (2000) Taube nuss is a novel gene essential for the survival of pluripotent cells of early mouse embryos Development 127 5449-5461

Wang S, Gebre-Medhin S, Betsholtz C et al. (1998) Targeted disruption of the mouse phospholipase $C$ beta3 gene results in early embryonic lethality FEBS Letters 441 261-265
Wang Y, Cortez D, Yazdi P, Neff N, Elledge SJ and Qin J (2000) BASC, a super complex of BRCA1-associated proteins involved in the recognition and repair of aberrant DNA structures Genes and Development 14927 939

Weber RJ, Pedersen RJ, Wianny F, Evans MJ and Zernicka-Goetz $M$ (1999) Polarity of the mouse embryo is anticipated before implantation Development 126 5591-5598

Whitehouse CJ, Taylor RM, Thistlethwaite A, Zhang H, Karimi-Busheri F, Lasko DD, Weinfeld $\mathbf{M}$ and Caldecott KW (2001) XRCC1 stimulates human polynucleotide kinase activity at damaged DNA termini and accelerates DNA single-strand break repair Cell 104 107-117

*Wianny F and Zernicka-Goetz M (2000) Specific interference with gene function by double-stranded RNA in early mouse development Nature Cell Biology 2 70-75

Wiles MV, Vauti F, Otte J et al. (2000) Establishment of a gene-trap sequence tag library to generate mutant mice from embryonic stem cells Nature Genetics 24 13-14

Witke W, Sutherland JD, Sharpe A, Arai M and Kwiatkowski DJ (2001) Profilin I is essential for cell survival and cell division in early mouse development Proceedings National Academy of Sciences USA 983832 3836

Wright FA, Lemon WJ, Zhao WD et al. (2001) A draft annotation and overview of the human genome Genome Biology 2 Research 0025.10025.18

Xanthoudakis S, Smeyne RJ, Wallace JD and Curran T (1996) The redox/DNA repair protein, Ref-1, is essential for early embryonic development in mice Proceedings National Academy of Sciences USA 93 8919-8923

Yang J, Goldstein JL, Hammer RE, Moon YA, Brown MS and Horton JD (2001) Decreased lipid synthesis in livers of mice with disrupted Site1 protease gene Proceedings National Academy of Sciences USA 98 13 607-13612

Yoshida K, Kuo F, George EL, Sharpe AH and Dutta A (2001) Requirement for CDC45 for postimplantation mouse development Molecular and Cellular Biology 21 4598-4603

Zamore PD (2002) Ancient pathways programmed by small RNAs Science 296 1265-1273

*Zernicka-Goetz M (2002) Patterning of the embryo: the first spatial decisions in the life of a mouse Development 129 815-829

Zhu J, Petersen S, Tessarollo L and Nussenzweig A (2001) Targeted disruption of the Nijmegen breakage syndrome gene NBS1 leads to early embryonic lethality in mice Current Biology 11 105-109

Zhuo D, Zhao WD, Wright FA et al. (2001) Assembly, annotation, and integration of UNIGENE clusters into the human genome draft Genome Research 11 904-918

Ziomek CA and Johnson MH (1980) Cell surface interaction induces polarization of mouse 8-cell blastomeres at compaction Cell 21 935942

Zipperlen P, Fraser AG, Kamath RS, Martinez-Campos $\mathbf{M}$ and Ahringer J (2001) Roles for 147 embryonic lethal genes on C. elegans chromosome I identified by RNA interference and video microscopy EMBO Journal 20 3984-3992

Zizioli D, Meyer C, Guhde G, Saftig P, von Figura K and Schu P (1999) Early embryonic death of mice deficient in $\gamma$-adaptin Journal of Biological Chemistry 274 5385-5390

Zmuidzinas A, Fischer KD, Lira SA, Forrester L, Bryant S, Bernstein A and Barbacid M (1995) The vav proto-oncogene is required early in embryogenesis but not for hematopoietic development in vitro. $E M B O$ Journal 14 1-11 